\title{
Synthesis of some Pyrimidine-2-one and Pyrimidine-2-thione Compounds
}

\author{
Hiba A. Ebraheem \\ Department of Chemistry \\ College of Science \\ University of Mosul
}

E- mail:hiba.ameen80@yahoo.com

(Received 10/5/2012;Accepted 10/9/2012)

\begin{abstract}
An efficient synthesis of chalcones (1-7) was achived by condensation of substituted benzaldehyde with substituted acetophenone in ethanolic sodium hydroxide $(50 \%)$. The chalcones were reacted with urea and thiourea to give the pyrimidinones(8-14) and pyrimidinethiones(15-21) respectively. All the prepared compounds were confirmed by the available physical and spectral methods.
\end{abstract}

Keywords: pyrimidine-2-one, pyrimidine-2-thione, heterocyclic compound, chalcones.

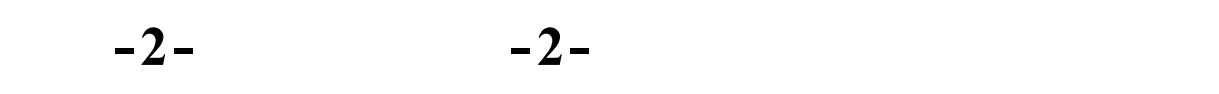

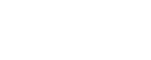

مة تحضير الجالكونات(7-1) من تكاق البزالديهايد المعوض مع الاسيتوفينون المعوض في محلول

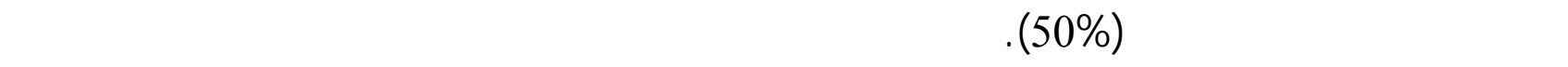
البريمينينون (14 -8) والبريمينينايون (21 -15) على التوالي. ششخصت جمبع المركبلت المحضرة بلستخدالم الطرق الفيزياوية والطيفية المتوفرة.

الكاملت الدالة: البريمينينونوالبريميينثايون، المركبلت الحلقية غيرالمتجلنسة، الجالكونات.

\section{INTRODUCTION}

The hetrocyclic molecules are of biological interest due to their potential physical and chemical properties (Brown,1998). Among these the pyrimidine compounds which occupy aunique position in pharmaceutical chemistry. They are components of nucleic acids. The important pyrimidine compounds have diverse applications as anti-bacterial (Pershin et al.,1972), fungicidal (Metolcsy,1971), analgesics (Regnier et al., 1972), anti-inflammatory (Winter et al.,1962) and anti-tumor agents (Suguira et al.,1973). Nowadays the one step 
method involving three component condensation using different reagents (Dipti et al., 2010) are popular in synthetic organic chemistry for the synthesis of heterocyclic compounds. They are present in nature and are of great significance to life because their structural subunits exist in many natural products such as vitamins, hormones, antibiotics (Yuhong and Varma, 2006). Hence, they have attracted considerable attention in the design of biologically active molecules.(Kawamoto et al., 2003).A practical method for the synthesis of such compounds is of great interest in synthetic organic chemistry. (Junichi et al., 2000).

The chalcones were synthesized by condensation of different substituted aldehydes withacetophenones (Dhaval and Dhrubo, 2009), through claisen - Schmidt condensation reaction in ethanolic $\mathrm{NaOH}$ solution (Vogel, 2006).

Chalcones either natural or synthetic are known to exhibit various biological activities. They have been reported to possess anti-oxidant, anti-leishmanial, anti-inflammatory antitumor and anti-bacterial activity. The presence of reactive $\alpha, \beta$ - unsaturated keto function in chalcone is found to be responsible for their anti microbial activity (Larsen et al., 2005).

Chalcones considered as a precursor of flavonoids and isoflavonoids and they are present in edible plants (stevens et al., 2000) and have also been shown to display a diverse array of pharmacological activities, such as anti- protozoal and antihyperglycemic properties (Liu et al., 2001) (Satyanarayana et al., 2004). In the present research, a series of chalcones was prepared as a synthon to synthesize new pyrimidine and pyrimidine thione compounds.

\section{EXPERIMENTAL}

Melting points (M.P) were measured on Electrothermal, Gallenkamp melting point apparatus and are uncorrected.Infrared (FTIR) spectra were recorded as $(\mathrm{KBr})$ disc using a Bruker, FT.IR spectrophotometer tensor 27. Ultraviolet (U.V) spectra were performed on shimadzu UV- visible spectrophotometer UV-1650 PC using chloroform as a solvent.

\section{A. Synthesis of 1,3-diaryl-2-propen-1-one (1-7) (Vogel, 1974):}

To a stirred and ice cooledsolution of ( 0.055 mole, $50 \%)$ sodium hydroxide in $(20$ $\mathrm{ml})$ of water and $(12.5 \mathrm{ml})$ of ethanol, a freshly distilled substituted acetophenone $(0.043$ mole) was added followed by $(0.043$ mole $)$ of substituted benzaldehyde. The temperature of the mixture was mentained at $\left(20-25^{\circ} \mathrm{C}\right)$ with vigorous stirring for $(2-3$ hours), until the mixture became thick. The mixture was left in the refrigerator overnight. The product was filtered off under vacuum and washed with water until the filterates became neutral to litmus paper, washed with $(20 \mathrm{ml})$ ice-cold ethanol, then recrystalized from ethanol. The physical properties and the spectral data were listed in Table(1). 
Table 1: The physical properties and the spectral data for compounds(1-7).

\begin{tabular}{|c|c|c|c|c|c|c|c|}
\hline \multirow{2}{*}{$\begin{array}{c}\text { Compd. } \\
\text { No. }\end{array}$} & \multirow[t]{2}{*}{ Ar } & \multirow[t]{2}{*}{$\mathbf{X}$} & \multirow[t]{2}{*}{ M.P ${ }^{\circ} \mathrm{C}$} & \multirow{2}{*}{$\begin{array}{c}\% \\
\text { yield }\end{array}$} & \multirow{2}{*}{$\begin{array}{c}\mathrm{UV} \\
\left.(\mathrm{CH} \mathrm{Cl})_{3}\right) \\
\lambda_{\max }(\mathrm{nm})\end{array}$} & \multicolumn{2}{|c|}{$\begin{array}{c}\text { FT.IR (KBr) } \\
\text { v } \mathrm{Cm}^{-1}\end{array}$} \\
\hline & & & & & & $\mathrm{C}=\mathbf{O}$ & $\mathrm{C}=\mathrm{C}$ \\
\hline 1 & $\begin{array}{l}\text { 3,4-Dichloro } \\
\text { benzaldehyde }\end{array}$ & $\mathrm{p}-\mathrm{Br}$ & $110-112$ & 85 & 430 & 1720 & 1635 \\
\hline 2 & 3-Indol carbaxaldehyde & $\mathrm{p}-\mathrm{Br}$ & $170-172$ & 68 & 400 & 1685 & 1637 \\
\hline 3 & 9-Anthraldeh yde & $\mathrm{p}-\mathrm{CH}_{3}$ & $122-124$ & 75 & 420 & 1684 & 1650 \\
\hline 4 & p-chlorobenzaldehyde & $\mathrm{p}-\mathrm{Cl}$ & $88-90$ & 90 & 380 & 1720 & 1630 \\
\hline 5 & 2-piperenal & $\mathrm{p}-\mathrm{NO}_{2}$ & $168-170$ & 90 & 430 & 1695 & 1655 \\
\hline 6 & 2-piperonal & $\mathrm{p}-\mathrm{OMe}$ & $118-120$ & 90 & 420 & 1720 & 1635 \\
\hline 7 & p-Touldehyde & p-OMe & $128-130$ & 90 & 400 & 1720 & 1655 \\
\hline
\end{tabular}

\section{B. Synthesis of 3,4-dihydro -4,6-diaryl pyrimidine-2-(1H)-one (8-14)(Vogel, 2006)}

To amixture of chalcone $(1-7)(0.025$ mole) and urea $(3.0 \mathrm{~g}, 0.05$ mole), an aqueous sodium hydroxide solution $(30 \%, 15 \mathrm{~m} \ell)$ and ethanol $(75 \mathrm{~m} \ell)$ were added with stirring. The mixture was refluxed for ( 2 hours). The mixture was poured with stirring on $(125 \mathrm{ml})$ of water, then allowed to stand for (15 minutes). The mixture was filtered, and the filtrate was cooled in an ice-bath and acidified with concentrated hydrochloric acid. The precipitate was filtered off under reduce pressure then recrystallized from ethanol. The physical and the spectral data were listed in Table (2).

Table2: The physical properties and the spectral data of compounds (8-14).

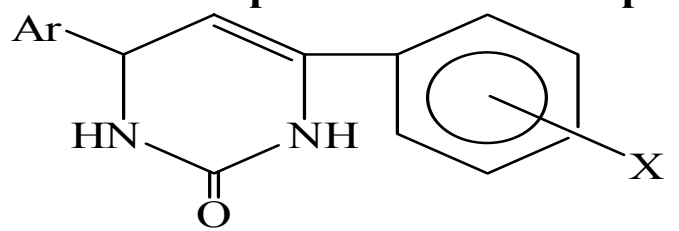

\begin{tabular}{|c|c|c|c|c|c|c|}
\hline \multirow{2}{*}{$\begin{array}{c}\text { Compd. } \\
\text { No. }\end{array}$} & \multirow{2}{*}{ M.P } & \multirow{2}{*}{$\mathbf{C}$} & $\begin{array}{c}\text { yield } \\
\mathbf{\%}\end{array}$ & \multirow{U}{*}{$\begin{array}{c}\text { UV(CH Cl } \\
\lambda_{\text {max }} \text { (nm) }\end{array}$} & \multicolumn{3}{|c|}{ FT.IR (KBr) } \\
\cline { 5 - 7 } & & & & \multicolumn{3}{|c|}{ v $\mathbf{C m}^{-1}$} \\
\hline 8 & 220 & 70 & 320 & 1676 & 1630 & 3400 \\
\hline 9 & $155-157$ & 65 & 340 & 1685 & 1635 & 3402 \\
\hline 10 & $226-228$ & 50 & 330 & 1684 & 1634 & 3413 \\
\hline 11 & $118-120$ & 70 & 320 & 1675 & 1630 & 3442 \\
\hline 12 & 280 & 50 & 380 & 1685 & 1630 & 3450 \\
\hline 13 & $230-232$ & 50 & 350 & 1672 & 1625 & 3446 \\
\hline 14 & $60-62$ & 50 & 330 & 1686 & 1630 & 3400 \\
\hline
\end{tabular}




\section{B. Synthesis of 3,4-dihydro-4,6- diaryl pyrimidine-2 (1H) thiones (15-21), \\ (Krein et al., 1993).}

To a mixture of aqueous sodium hydroxide solution $(6 \mathrm{ml}, 50 \%)$ and benzene $(25 \mathrm{ml})$, tetrabutyl ammonium bromide (TBAB) $(0.2 \mathrm{~g}, 0.0015$ mole $)$ and thiourea $(0.005$ mole $)$ were added with stirring (for 5 minutes). To this mixture the chalcone $(0.005$ mole) was added with stirring. The stirring was continued for $24-72$ minutes at $40-60^{\circ} \mathrm{C}$. The organic layer was separated and washed several times with water until become clear to remove the catalyst and base, then dried with anhydrous magnesium sulfate. The solvent was evaporated under reduced pressure and the precipitate was recrystallized from chloroform. The physical and spectral data were listed inTable (3).

Table3:The physical properties and the spectral data for compounds (15-21).

\begin{tabular}{|c|c|c|c|c|c|c|c|c|}
\hline \multirow{2}{*}{$\begin{array}{c}\text { Compd. } \\
\text { No. }\end{array}$} & \multirow{2}{*}{ 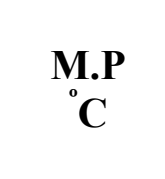 } & \multirow{2}{*}{$\begin{array}{c}\% \\
\text { yield }\end{array}$} & \multirow{2}{*}{$\begin{array}{c}\text { UV } \\
\text { (Ethanol) } \\
\lambda_{\max }(\mathbf{n m})\end{array}$} & \multirow{2}{*}{$\begin{array}{l}\text { Time } \\
\text { (min) }\end{array}$} & \multirow{2}{*}{$\underset{{ }^{\circ} \mathrm{C}}{\text { Temp }}$} & \multicolumn{3}{|c|}{$\begin{array}{l}\text { FT.IR (KBr) } \\
\quad \text { v } \mathbf{C m}^{-1}\end{array}$} \\
\hline & & & & & & $\mathrm{C}=\mathrm{S}$ & $\mathrm{C}=\mathrm{C}$ & $\mathrm{N}-\mathrm{H}$ \\
\hline 15 & $250-252$ & 60 & 420 & 48 & 50-55 & 1160 & 1650 & 3400 \\
\hline 16 & $100-102$ & 70 & 320 & 72 & $45-50$ & 1164 & 1645 & 3450 \\
\hline 17 & $230-233$ & 70 & 330 & 24 & $55-60$ & 1165 & 1657 & 3420 \\
\hline 18 & $150-152$ & 60 & 320 & 48 & $40-45$ & 1160 & 1646 & 3400 \\
\hline 19 & $220-222$ & 70 & 310 & 48 & $55-60$ & 1167 & 1655 & 3430 \\
\hline 20 & $160-162$ & 60 & 330 & 24 & $50-55$ & 1162 & 1654 & 3450 \\
\hline 21 & $210-212$ & 60 & 330 & 72 & $55-60$ & 1160 & 1650 & 3420 \\
\hline
\end{tabular}

\section{RESULT AND DISCUSSION}

The carbonyl compounds are considered as a precursor for synthesis of many important heterocyclic compounds, through their reaction with other different compounds. This work involves preparation of chalcones which reacted consequently with urea and thiourea to form the pyrimidine-2-ones, pyrimidine-2-thiones respectively. The synthetic routes are shown in Scheme (1).

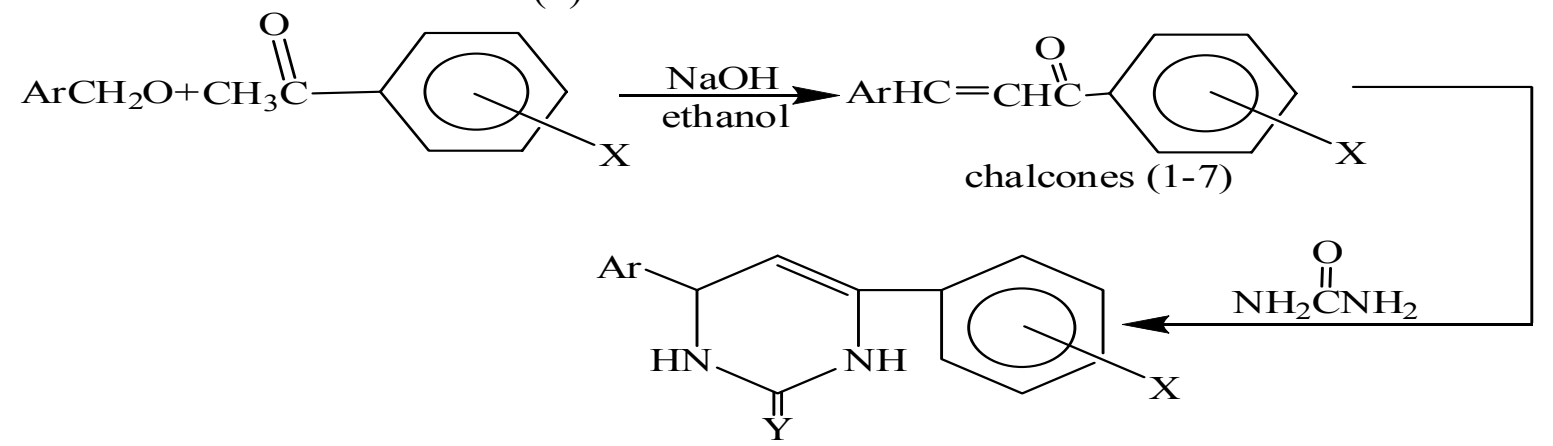

$\mathbf{Y}=\mathbf{O}, \mathbf{S}$

Scheme 1: Synthesis of pyrimidine-2-ones and pyrimidine-2-thiones. 
The chalcones (1-7) have been prepared by condensation of aromatic aldehyde with substituted acetophenone under basic conditions (ethanolic sodium hydroxide solution).

The structure of these chalcones was established by spectroscopic methods (Table 1). The FT, IR spectra ( $\mathrm{KBr}$ disk) (Williams et al., 1973) showed a strong absorption bands at $\left(1720-1684 \mathrm{~cm}^{-1}\right)$ for the $\mathrm{C}=\mathrm{O}$ bondstreaching, and bands at $\left(1655-1630 \mathrm{~cm}^{-1}\right)$ for $(\mathrm{C}=\mathrm{C})$ bond stretching. The UV spectra (AL-Hajjar et al., 1980) showed maximum absorption at the wave length $\left(\lambda_{\max }\right) 380-430 \mathrm{~nm}$ due to the extension of the $\pi$ system (Parikh,1974). The condensation of compounds (1-7) with urea under basic conditions (aqueous sodium hydroxide solution) afforded pyrimidine-2-one compounds (8-14). The reaction may be proceed through nucleophilic1,2-addition (Claisen addition) or 1,4-addition (Michael addition) (Scheme 2). According to the theoretical calculations of the heat of formation (H.F), and the steric energy (S.E) (using the semiempirical method, Chem. Office version 2006), the reaction may be proceed via Michael addition. By Michael route the heat of formation and the steric energy of compound $8 \mathrm{a}$ are -33.681 and $20.473 \mathrm{Kcal} / \mathrm{mole}$ respectively, while their values are -27.751 and $24.250 \mathrm{Kcal} / \mathrm{mole}$ respectively for compound $8 \mathrm{~b}$ (Claisen route).

The structure of compounds (8-14) was established by spectroscopic methods (Table 2). The FT, IR spectra showed a strong absorption bands at $\left(1686-1672 \mathrm{~cm}^{-1}\right)$ for the $\mathrm{C}=\mathrm{O}$ bond stretching and a bands at $\left(1635-1625 \mathrm{~cm}^{-1}\right)$ for the $\mathrm{C}=\mathrm{C}$ bond stretching in addition to broad bands at (3450-3400 $\left.\mathrm{cm}^{-1}\right)$ for the N-H bond stretching.

The U.V spectra of compounds (8-14) (Jackman, 1978) showed $\lambda_{\max }$ at $320-380 \mathrm{~nm}$, i.e, they showed a blue shift relative to the $\lambda_{\max }$ exhibited by chalcones. This blue shift attributed to the destruction of the conjugation.

On the other hand, the condensation of compounds (1-7) with thiourea under phase transfer catalysis afforded the pyrimidine-2-thione compounds (15-21). The structure of these compounds was established on the bases of spectroscopic methods (Table 3).

The FTIR spectra (Williams,1973) showed three characteristic bands at (1167-1160), (1657-1645) and (3450-3400) $\mathrm{cm}^{-1}$ attributed to $\mathrm{C}=\mathrm{S}, \mathrm{C}=\mathrm{C}$ and N-H (broad) bond stretching respectively. The U.V spectra (Jackman,1978) showed absorption bands at shorter wavelength (blue shift) at $310-420 \mathrm{~nm}$ relative to the chalcones $\left(\lambda_{\max }=380-430 \mathrm{~nm}\right)$. The suggested mechanism for the reaction of chalcones with thiourea is illustrated in Scheme (2).

According to the theoretical calculations the preferred mechanistic route is the Michael addition (H.F and S.E for compound $15 \mathrm{a}$ are -25.089 and $24.232 \mathrm{Kcal} / \mathrm{mole}$ respectively). This product is more stable than $15 \mathrm{~b}$ (formed via Claisen addition H.F and S.E are 19.716 and $29.158 \mathrm{Kcal} /$ mole respectively). 


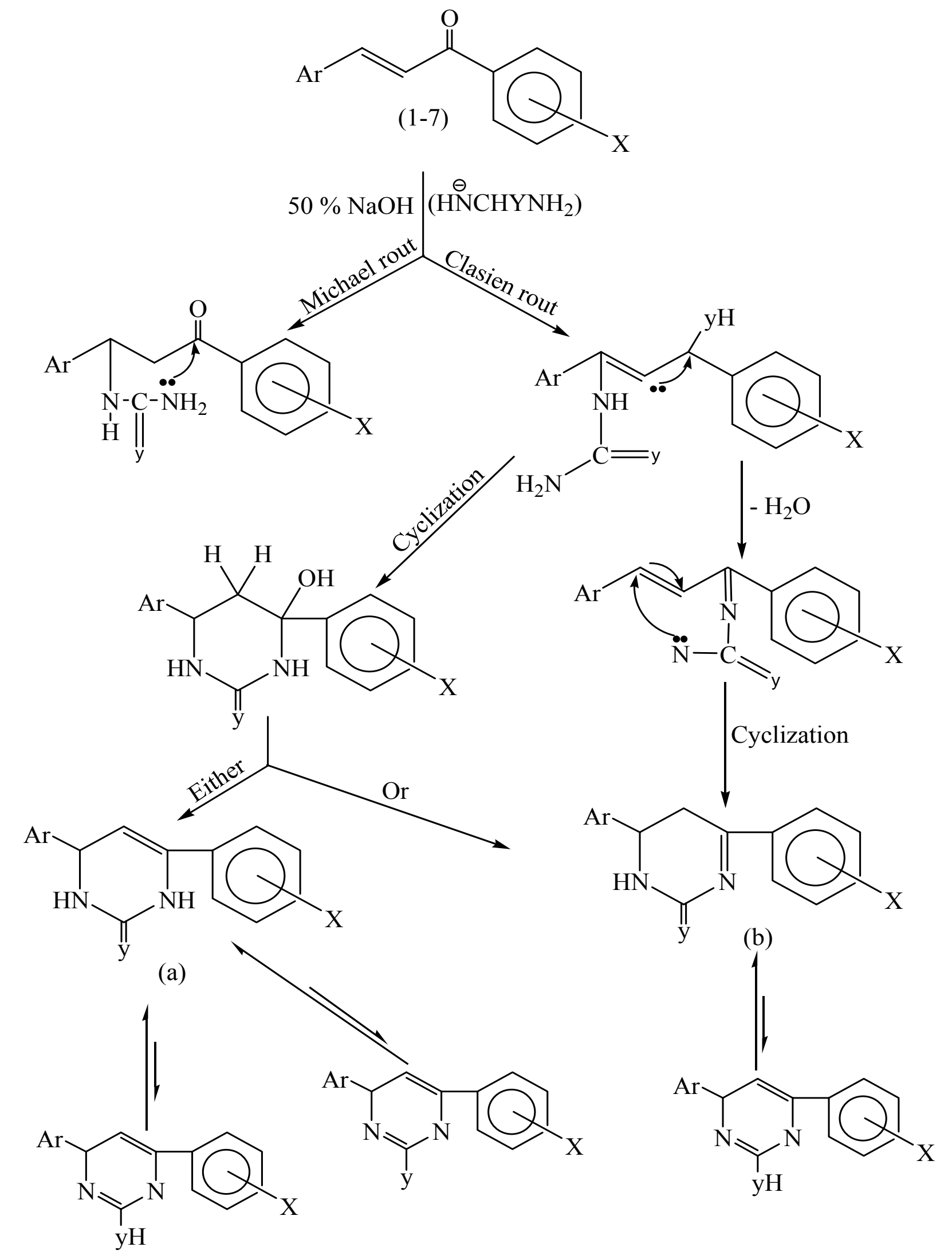

$\mathbf{y}=\mathbf{O}, \mathbf{S}$

Scheme 2: Reaction of chalcone (1-7) with urea and thiourea. 


\section{REFERENCES}

Al-Hajjar, F.H.; Al-Farkh, Y.A. ; Hamound, H.S. (1980). Synthesis of chalcones. Can. J. Chem. 57, 2734.

Brown, R.C.D. (1998). Recent development in solid phase organic synthesis. J. Chem. Soc. Perkin. Trans 1. 3293-3320.

Dhaval, M.P.; Dhrubo, J. S. (2009). Synthesis and antimicrobial screening by sar studies of synthesize chalcone derivatives having heterocyclic rings. Inter. J. Pharm Sci., 1(1), 35-41.

Dipti, R.P.; Sonali, M. S.; Madhkar, B.D.; Parshant, V. A. (2010). Synthesis and antimicrobial screening of hetrerocyclic compounds. Open Catalysis J., 3, 83-86.

Jackman, L.M. (1978). "Structure Determination in Organic Chemistry". Longman and Butter worth and Co publishers. Ltd, pp. 40-44.

Junchi, K.; Kazuki, F.; Naok, I.; Yasuyo, Y.; Hiroyay (2000). Synthesis and characterization of new chalcones compounds. Chem. Pharm. Bull., 48(7), 1051-1054.

Kawamoto, M.; lkeda, T.; Mori, A.; Sekinguchi, A.; Masui, K.; Horie, M.; Osakada, M. (2003). Synthesis of heterocyclic compounds. J. Am. Chem. Soc., 125,1700.

Krein, E.B.; Aizenshat, Z. (1993). Studies of heterocyclic compound. J. Org. Chem. 58, $6103-6108$.

Liu, M.; Wilairat, P.; GO, M. L. (2001). Studies of pyrimidine-one structure. J. Med. Chem., 44, 4443-4452.

Metolcsy, G. (1971). Structure-activity correlations and mode of action of some selected types of antifungal compounds. World Rev. Pest Contr., 10, 50-59; [chem. Abstr 1972, 76, 82031s].

Parikh, V.M. (1974). "Absorption Spectroscopy of Organic Compounds ", Longeman and Co publishers Ltd , pp. 247-252.

Pershin, N. G.; Sherbakova, L. I.; Zykova, T.N.; Sakolova, V. N. (1972). Antibacterial activity of pyrimidine and pyrrolo-(3,2-d)-pyrimidine derivatives. Pharmacol. Taksiko, 35, 466-471.

Regnier, G. L.; Canevar, R. J.; Canevar, J.C.; Douarec, L.; Halstop, S. ; Daussy (1972). J. Triphenyl propyl piprazine derivatives as new potent analgesic. J. Med. Chem., 15, 295-301.

Satyanarayana, M.; Tiwari, P.; Tripathi, B. K.; Pratap, R. (2004). Biological activities of chalcone compounds. Bioorg. Med. Chem. 12, 883-889.

Stevens, J. F.; Taylor, A.V.; Nickerson, G. B.; Ivancic, M. (2000). Chalcone Chemistry. Phyto. Chem. , 53 ,759-775.

Suguira, A. F.; Schmid, M. M.; Brown, F. G. (1973). Effect of compounds on a spectrum of rat tumors. Cancer Chemother. Rep. ; Part 2, 3(1), 231-238.

Vogel, A. (2006). "Practical Organic Chemistry". Longeman and New York publishing. Ltd 6th ed., pp.1151-1152.

Vogel, A. (1951). "Practical Organi Chemistry ". Longeman and New York publishing. Ltd 2nd ed. pp.676- 681.

Williams, D.H. ; Fleming, I. (1973) . "Spectroscopic Methods in Organic Chemistry ". 2nd ed. Mcgraw-Hill, England. 18 p. 
Winter, C. A.; Fisley, E.A.; Nuss, G.W. (1962). Carrageen in induced edema in hind paw of the rat as an assay for anti-inflammatory. Drugs. Proc. Soc. Exp. Med. 111,544547.

Yuhoug, J. U.; Varma, R.S. (2006). Studies on some heterocyclic enities. J. Org. Chem. 71,135 . 